\title{
EBF recommendation on practical management of critical reagents for antidrug antibody ligand-binding assays
}

\author{
Susanne Pihl ${ }^{1}$, Barry WA van der Strate ${ }^{\ddagger}, 2$, Michaela Golob ${ }^{3}$, Janka Ryding ${ }^{4}$, Laurent \\ Vermet $^{5}$, Birgit Jaitner ${ }^{6}$, Joanne Goodman ${ }^{7}$ \& Philip Timmerman*,8 \\ ${ }^{1}$ Ascendis Pharma A/S, Copenhagen, Denmark \\ ${ }^{2}$ University Medical Center Groningen, The Netherlands \\ ${ }^{3}$ Nuvisan GmbH, Grafing, Germany \\ ${ }^{4}$ Svar Life Science Wieslab AB, Malmoe, Sweden \\ ${ }^{5}$ Sanofi Research \& Development, Montpellier, France \\ ${ }^{6}$ Novartis Pharma AG, Basel, Switzerland \\ ${ }^{7}$ AstraZeneca, Cambridge, UK \\ ${ }^{8}$ European Bioanalysis Forum, Havenlaan 86c b204, 1000 Brussels, Belgium \\ *Author for correspondence: Tel.: +32 4799101 32; chair@e-b-f.eu \\ $¥$ At the time of the team discussion, employed by PRA Health Sciences, Assen, The Netherlands
}

Immunogenicity assays are required to measure antidrug antibodies that are generated against biotherapeutic modalities. As for any ligand-binding assays, critical reagents (CR) play a crucial role in immunogenicity assays, as the robustness and reliability of an assay are defined by the quality and long-term availability of these reagents. The current regulatory guidelines do not provide clear directions on how to implement and verify lot-to-lot changes of CR during an assay life cycle, or the acceptance criteria that should be used when implementing new lots of CR. These aspects were extensively discussed within the European Bioanalysis Forum community. In this paper, CR for immunogenicity assays are identified and the minimum requirements for introducing new lots of $C R$ in immunogenicity assays are described.

First draft submitted: 21 August 2019; Accepted for publication: 2 October 2019; Published online: 28 October 2019

Keywords: antidrug antibody assay • critical reagents $\bullet$ major change $\bullet$ minor change

Critical reagents (CR) play an important part in ligand-binding assays (LBA). The European Bioanalysis Forum (EBF) has previously provided a recommendation on the life cycle management of CR in LBA pharmacokinetic (PK) assay [1] and will herein provide a recommendation for antidrug antibody (ADA) assays to expand on the recommendation provided by the Global Bioanalysis Consortium (GBC) [2]. The qualitative nature of the ADA assay may present an added challenge compared with the quantitative PK assays (Table 1) as the changes of CR changes may have more impact on the assay. Further, ADA assays follow a step-wise testing approach and each test tier may have a different consideration for CR.

It is important to understand, if a change in CR impacts the performance of the functional assay and, as a result, should be considered as critical. For example, it should be remembered that an ADA assay is built around a positive control (PC) antibody that is surrogate in nature and that critical decisions during method development, such as concentrations of coating and detection reagents, minimum required dilution, specific processing steps are taken based on the results obtained with this surrogate PC. The nature of the PC antibody(ies) used may suggest sensitivity and drug tolerance that are reflective when assessing the immunogenicity of actual samples.

Currently the European Medicines Agency and US FDA are the only health authorities that have issued specific guidelines [3-7] for immunogenicity assays, whereas the Japanese Ministry of Health, Labor and Welfare has two publications but no official guidance document. The guidelines simply state that, "reagents need to be qualified and acceptance specifications set, at least for those, which are most important" [3], "FDA believes positive control or quality control $(Q C)$ samples are critical" and for detection reagents, it is stated that the nature of the detection is critical [7]. 
Table 1. Assay characteristics for pharmacokinetic and antidrug antibody assays.

\begin{tabular}{|c|c|c|}
\hline Description & PK assay & ADA assay \\
\hline Measurement type & Quantitative & $\begin{array}{l}\text { Qualitative and semiquantitative (titrations) } \\
\text { Tiered approach - multiple assay types }\end{array}$ \\
\hline Calibrator & $\begin{array}{l}\text { Well characterized reference } \\
\text { standard } \\
\text { Used in sample testing }\end{array}$ & $\begin{array}{l}\text { Use of a 'surrogate' positive control antibody, usually generated in animals } \\
\text { Negative control } \\
\text { No standard curve used in sample testing }\end{array}$ \\
\hline Control & Quality controls & System suitability controls \\
\hline Sensitivity & $\begin{array}{l}\text { Defined based on mass unit } \\
\text { concentration }\end{array}$ & $\begin{array}{l}\text { Defined in relation to the cut-point of the assay. Sensitivity is highly dependent on the surrogate } \\
\text { positive control antibody and may not be reflective of sensitivity in clinical samples. }\end{array}$ \\
\hline Assay format & $\begin{array}{l}\text { Usually a sandwich immunoassay } \\
\text { In-house generated or } \\
\text { commercially sourced }\end{array}$ & Depends on the assay format and tier of testing (LBA/CBA/SPR, etc.) \\
\hline
\end{tabular}

Unfortunately, these regulatory documents do not describe what processes underly these requirements, leaving the bioanalytical community to reach consensus on the best practices to define, qualify and monitor CR.

EBF herein provides a gap analysis of current publications and in addition provides a practical recommendation on the minimum assessment of CR in ADA assays. However, some scientific assessments proposed in the manuscript may be project-specific and may not be required for all projects. Cell-based immunogenicity assays, PK and biomarker assay reagents are out of scope for this recommendation.

\section{Review of the current recommendations}

It is generally agreed in the literature that verification of assay performance is needed when CR are changed, including the requirement for documentation of the new reagent's performance. A certificate of analysis (CoA), equivalent documentation or datasheet for the $\mathrm{CR}$ including, but not limited to, information regarding reagent identity, concentration, storage conditions and stability testing should also be available. A comprehensive list with recommendations regarding documentation is provided by the aforementioned GBC paper [2].

Table 2 offers a valuable insight into the bioanalytical community's perspective on CR from the current guidelines and scientific papers, but there are clear gaps that would benefit from more in-depth discussion. The major gaps are as follows:

- General practical recommendations on testing for reagent lot-to-lot changes of CR are provided, however the actual process and experiments are not presented in detail, neither are the impact of the different type of CR;

- Limited recommendations on life cycle management of reagents, for example, stability, expiry/re-testing and monitoring of assay performance, particularly in relation to expiry dates of commercial reagents provided by vendors versus in-house established dates for these reagents.

\section{Identifying CR \& non-CR}

Within the EBF community, multiple discussions were held on which reagents should be considered as CR for immunogenicity assays. As a general statement, assay reagents are deemed to be critical, if they have a direct impact on the assay performance due to their quality, structure, nature or specificity. In addition, the possible consequences for introducing new lots of $\mathrm{CR}$ in immunogenicity assays were addressed. Table 3 provides an example overview of the different assay reagents that are used in immunogenicity assays and if and when, these reagents are considered to be critical.

The primary assessment is to classify the source of reagent criticality. For this, one should consider two main parameters. The first one is the probability that any issue occurs with a reagent. The second one is the impact that this reagent will have in the ADA assay in case of an issue. This criticality risk could be plotted as shown in Figure 1 to help in the classification. By using this approach, resources could be forecast and well addressed to focus primarily on high risk level (red boxes in the figure), and time could also be saved.

CR can be obtained using two different approaches: using smaller or larger batches. Using smaller batches of CR requires multiple testing for lot-to-lot changes to confirm performance between lots, however long-term stability is not required. Using larger batches of CR limits the testing of lot-to-lot changes. It is recommended for ADA assays to use large batches of CR, if possible, to ensure that results can easily be compared over long periods of time. 
Table 2. Overview of current guidelines and White Papers.

\begin{tabular}{|c|c|c|c|c|}
\hline Author (year) & Definition of critical reagents & $\begin{array}{l}\text { Process recommendation for lot-lot } \\
\text { changes }\end{array}$ & Recommendation for reagent stability & Ref. \\
\hline EMA (2008) & $\begin{array}{l}\text { Not defined, however, mention PC and } \\
\text { NC are critical assay reagents }\end{array}$ & Qualified reagents should be used & Not mentioned & [3] \\
\hline EMA (2012) & $\begin{array}{l}\text { Binding proteins } \\
\text { Conjugates } \\
\text { Antibodies } \\
\text { Aptamers }\end{array}$ & Verification of method performance & $\begin{array}{l}\text { Storage conditions and maintenance } \\
\text { should be documented }\end{array}$ & [4] \\
\hline $\begin{array}{l}\text { EMA (2014, } \\
2015,2017)\end{array}$ & Not defined & Qualified reagents should be used & $\begin{array}{l}\text { Appropriate storage (appropriately } \\
\text { [lyophilized or frozen at a suitable } \\
\text { temperature] } \\
\text { Characterize reagents }\end{array}$ & {$[5,6]$} \\
\hline FDA (2019) & Not defined & Not discussed & $\begin{array}{l}\text { Qualification and stability of critical } \\
\text { reagents is important for ensuring } \\
\text { consistent assay performance } \\
\text { Mentions: } \\
\text { - validation should include 'in-use stability } \\
\text { of critical reagents'. } \\
\text {-“Qualification and stability of critical } \\
\text { reagents... for ensuring consistent assay } \\
\text { performance” } \\
\text { - Usefulness of "evaluation short-term } \\
\text { stability ... and room-temperature stability } \\
\text { of positive control antibodies" }\end{array}$ & [7] \\
\hline $\begin{array}{l}\text { USP } 1106 \\
\text { (including } \\
1106.1 \text { ) }\end{array}$ & Not defined & $\begin{array}{l}\text { The reference lot and the new lot } \\
\text { should be compared by preparing assay } \\
\text { controls. However, in many cases a } \\
\text { reference lot may not be available for } \\
\text { conducting a comparison. In this case, } \\
\text { the new reagent should be tested and if } \\
\text { the assay behaves as expected, it may } \\
\text { be considered acceptable }\end{array}$ & $\begin{array}{l}\text { Life cycle management system for critical } \\
\text { reagents. } \\
\text { "Important consideration for life cycle } \\
\text { management of critical assay reagents is } \\
\text { the monitoring long-term reagent stability } \\
\text { under different storage conditions" }\end{array}$ & [8] \\
\hline $\begin{array}{l}\text { Mire-Sluis et al. } \\
(2004)\end{array}$ & Not defined & $\begin{array}{l}\text { "Test multiple reagent lots to ensure } \\
\text { vendor product specifications meet the } \\
\text { user's requirements" } \\
\text { Verification of method performance }\end{array}$ & $\begin{array}{l}\text { Investigate conjugate stability } \\
\text { Stability acceptance criteria ... should be } \\
\text { justified }\end{array}$ & [9] \\
\hline $\begin{array}{l}\text { Rup and O'Hara } \\
(2007)\end{array}$ & $\begin{array}{l}\text { Classifies critical reagents and describes: } \\
\text { "ligand-binding assay reagent } \\
\text { development and management } \\
\text { activities occur throughout the life cycle } \\
\text { of biopharmaceutical product" and } \\
\text { "... requirements for characterization } \\
\text { and documentation" } \\
\text { Conjugates } \\
\text { Antibodies } \\
\text { Cell lines }\end{array}$ & $\begin{array}{l}\text { Verification of method performance } \\
\text { Method re-optimization } \\
\text { Test original and new lots in parallel } \\
\text { Trend analysis }\end{array}$ & $\begin{array}{l}\text { Set default expiration dates for most } \\
\text { reagents } \\
\text { Trend analysis may extend reagent } \\
\text { expiration date }\end{array}$ & [10] \\
\hline $\begin{array}{l}\text { Shankar et al. } \\
(2008)\end{array}$ & Not defined & Not discussed & $\begin{array}{l}\text { Stability characterization may also include } \\
\text { stability of assay critical reagents such as } \\
\text { the quality controls, the coated assay plate } \\
\text { or chip (if applicable) and other critical } \\
\text { reagents (such as conjugates) }\end{array}$ & [11] \\
\hline $\begin{array}{l}\text { Staack et al. } \\
\text { (2011) }\end{array}$ & $\begin{array}{l}\text { "All assay reagent that define the assay } \\
\text { readout and whose quality have a direct } \\
\text { impact on assay performance" } \\
\text { Conjugates } \\
\text { Antibodies } \\
\text { Peptides } \\
\text { Receptors or ligands (incl. fragments) }\end{array}$ & $\begin{array}{l}\text { To minimize batch-to-batch } \\
\text { differences... reagents should be } \\
\text { generated based on reviewed } \\
\text { manufacturing protocols with defined } \\
\text { specifications... } \\
\text { Propose "large-batch-approach"... "to } \\
\text { support all required analyses" }\end{array}$ & $\begin{array}{l}\text { For long-term supply, consistent } \\
\text { manufacturing, QC strategies and } \\
\text { long-term stability of the } \\
\text { reagents... should be investigated } \\
\text { Monitor aggregation of reagents. } \\
\text { Characterize with functional and } \\
\text { biophysical methods }\end{array}$ & [12] \\
\hline $\begin{array}{l}\text { O'Hara et al. } \\
(2012)\end{array}$ & $\begin{array}{l}\text { Critical reagents are those essential } \\
\text { components of LBAs whose unique } \\
\text { characteristics are crucial to assay } \\
\text { performance and therefore, require } \\
\text { thorough characterization and } \\
\text { documentation. } \\
\text { Components with performance impact } \\
\text { Conjugates } \\
\text { Antibodies } \\
\text { Complex drugs/biologics } \\
\text { Solid supports } \\
\text { Matrix }\end{array}$ & $\begin{array}{l}\text { Depends on extent of change and } \\
\text { expected impact } \\
\text { Verification of method performance } \\
\text { Method acceptance criteria established } \\
\text { a priori } \\
\text { Lot-specific batch record }\end{array}$ & $\begin{array}{l}\text { Storage conditions and maintenance } \\
\text { should be documented } \\
\text { Trend analysis may extend reagent expiry } \\
\text { date }\end{array}$ & [13] \\
\hline
\end{tabular}


Table 2. Overview of current guidelines and White Papers (cont.).

\begin{tabular}{|c|c|c|c|c|}
\hline Author (year) & Definition of critical reagents & $\begin{array}{l}\text { Process recommendation for lot-lot } \\
\text { changes }\end{array}$ & Recommendation for reagent stability & Ref. \\
\hline $\begin{array}{l}\text { Geist et al. } \\
\text { (2013) }\end{array}$ & $\begin{array}{l}\text { The term "critical reagent' has been } \\
\text { defined as those essential components } \\
\text { used in LBAs whose unique } \\
\text { characteristics impact assay } \\
\text { performance" }\end{array}$ & $\begin{array}{l}\text { "For critical reagents used in validated } \\
\text { methods, we require that new lots or } \\
\text { batches of the reagent undergo a } \\
\text { systematic assay qualification prior to } \\
\text { release for use in the LBA" } \\
\text { "Detailed physicochemical and } \\
\text { biophysical assessments can provide } \\
\text { critical comparative information } \\
\text { between new and previously qualified } \\
\text { lots of the reagent, and in the case of } \\
\text { conjugated reagents, estimate label } \\
\text { incorporation efficiency and } \\
\text { reproducibility" } \\
\text { "Characterization of critical reagents is } \\
\text { to provide a molecular 'fingerprint' for } \\
\text { each reagent" }\end{array}$ & $\begin{array}{l}\text { "Analysis of protein modifications may also } \\
\text { provide insight into critical reagent } \\
\text { stability (freeze-thaw, temperature and } \\
\text { storage and so on) and help define 'best } \\
\text { practices' for the implementation of a } \\
\text { process for maintaining critical reagents" }\end{array}$ & [14] \\
\hline $\begin{array}{l}\text { O'Hara and } \\
\text { Theobald (2013) }\end{array}$ & Components with performance impact & $\begin{array}{l}\text { Verification of method performance } \\
\text { Method acceptance criteria established } \\
\text { a priori }\end{array}$ & $\begin{array}{l}\text { Expiry dates should be based on } \\
\text { formulation, storage conditions and } \\
\text { available biophysical and functional data }\end{array}$ & [15] \\
\hline $\begin{array}{l}\text { Xu and Weant } \\
\text { (2013) }\end{array}$ & $\begin{array}{l}\text { Conjugates } \\
\text { Antibodies } \\
\text { Drugs/biologics } \\
\text { Platform-specific reagents } \\
\text { Cell lines } \\
\text { Matrix receptors or ligands }\end{array}$ & $\begin{array}{l}\text { Verification of method performance } \\
\text { Similarity assessment in other words, } \\
\text { test original- and new lots in parallel }\end{array}$ & Investigate conjugate stability & [16] \\
\hline $\begin{array}{l}\text { King et al. } \\
\text { (2014) }\end{array}$ & $\begin{array}{l}\text { "Some reagents are critical, and their } \\
\text { changes significantly alter or curtail the } \\
\text { performance of the assay that relies on } \\
\text { them" } \\
\text { Drugs/biologics } \\
\text { Conjugates } \\
\text { Antibodies } \\
\text { Proteins } \\
\text { Peptides } \\
\text { Matrix }\end{array}$ & $\begin{array}{l}\text { Verification of method performance } \\
\text { Similarity assessment in other words, } \\
\text { test original- and new lots in parallel (if } \\
\text { available) } \\
\text { Minor lot changes require one run with } \\
\text { minimum three control levels } \\
\text { (biomarker, PK and immunogenicity) } \\
\text { Major lot changes require three runs } \\
\text { with minimum three control levels } \\
\text { (biomarker, PK and immunogenicity) }\end{array}$ & $\begin{array}{l}\text { Trend analysis may extend reagent expiry } \\
\text { date } \\
\text { "The authors identified current best } \\
\text { practices and provided recommendations } \\
\text { for critical reagent lot changes, stability } \\
\text { management, and documentation" }\end{array}$ & [17] \\
\hline Bradford (2015) & $\begin{array}{l}\text { Reagents that are specific to the analyte } \\
\text { for example, } \\
\text { Drugs/biologics } \\
\text { Conjugates } \\
\text { Antibodies } \\
\text { Matrix } \\
\text { Receptors or ligands }\end{array}$ & $\begin{array}{l}\text { Verification of method performance } \\
\text { Minor lot changes with one run with } \\
\text { full set of QCs, assuring that the entire } \\
\text { assay range is evaluated } \\
\text { Major lot changes may require } \\
\text { minimum three precision/accuracy runs } \\
\text { (with previously established acceptance } \\
\text { criteria) or a partial validation }\end{array}$ & $\begin{array}{l}\text { Investigate conjugate stability } \\
\text { Trend analysis }\end{array}$ & [18] \\
\hline $\begin{array}{l}\text { Ishii-Watabe } \\
\text { et al. (2018) }\end{array}$ & Not defined & Method partial validation & $\begin{array}{l}\text { Storage conditions should be used that } \\
\text { ensure consistent quality }\end{array}$ & [19] \\
\hline
\end{tabular}

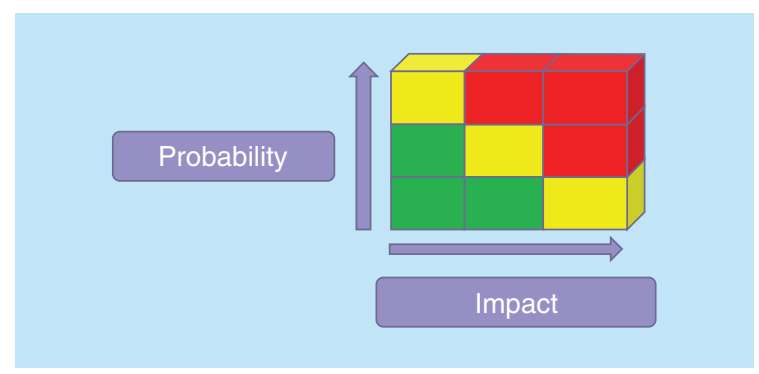

Figure 1. Critical reagents box-classification assessment in antidrug antibody assay.

Furthermore, it is not always possible to predict the availability of antibodies and the length of the clinical studies and thereby the amount of CR required needs to be carefully considered. 
Table 3. An EBF overview of critical and noncritical reagents for antidrug antibody assays.

\begin{tabular}{|c|c|c|}
\hline Reagent & $\begin{array}{l}\text { Considered as } \\
\text { critical }\end{array}$ & Examples \\
\hline Positive control antibody & Always & Monoclonal/polyclonal antibodies for preparation of LPC and HPC \\
\hline System suitability controls & Always & Positive controls \\
\hline Material for confirmatory/characterization assay & Always & $\begin{array}{l}\text { For example drug compound that is used for dosing, but also other } \\
\text { (multi-domain materials) that can be used for characterization of the } \\
\text { immune response (cross-reactivity) }\end{array}$ \\
\hline Labeled reagents for bridging assay & Always & $\begin{array}{l}\text { New batches of (labeled) coating/detection material. Both in-house or } \\
\text { commercially labeled }\end{array}$ \\
\hline Labeled reagents for direct assays & Potentially & $\begin{array}{l}\text { New batches of coating/detection material. Both in-house or } \\
\text { commercially-labeled }\end{array}$ \\
\hline Matrix & Potentially & $\begin{array}{l}\text { Preparation of assay controls including negative control serum, dilution } \\
\text { matrix for titration }\end{array}$ \\
\hline Coated surfaces & Potentially & Dependent on platform that is used for analysis \\
\hline Reagents used in specific processing steps & Potentially & Acid dissociation, SPEAD, PANDA, etc \\
\hline Standard reagents & Rarely & Blocking reagents, read buffers and substrates \\
\hline
\end{tabular}

Testing for reagent criticality during method development and validation is not always possible and it should be acknowledged this could also be performed during sample analysis or during transfer of the method to another facility. Reagents, which are noncritical in some assays, might be proven to be critical in other cases and may not be identified until the assay is transferred between laboratories. Additionally, the source of the CR could vary especially in different geographical regions and may require consideration [1].

The most practical strategy for identifying a difference between lots of CR is to run direct comparisons of different lots (head-to-head comparison) in the functional assay. Although this might not always be feasible due to the limited availability of different reagent lots during development and validation, it is always recommended to plan for sufficient reagent availability to enable bridging experiments between different reagent lots.

\section{Lot-to-lot changes of CR: recommendations \& considerations - a pragmatic approach}

Introducing new lots of CR during regulated bioanalysis may have several consequences for the reliability of the used assay and the obtained results. Table 4 gives an overview of the different parameters of immunogenicity assays that are affected when introducing new lots of CR.

Blank matrix is used for preparation of NC and PC, but also for titration of confirmed positive samples. Introducing a new lot of (pooled) blank matrix may affect the cut-point, induce drift of $\mathrm{NC}$ and $\mathrm{PC}$ responses, or impact on the sensitivity of the assay. It is important to consider that a change in disease-state (i.e., other populations) require additional validation, rather than solely performing assay-bridging experiments.

The introduction of new lots of PC antibodies can have major consequences for an immunogenicity assay. As mentioned earlier, the PC antibody defines all validation parameters of the assay framework, as the whole assay is designed around the surrogate PC. It is initially used to determine concentrations of coating and detection materials. Moreover, sensitivity and drug tolerance of an immunogenicity assay are determined by using this PC antibody. It may be necessary to evaluate the concentrations of low PC (LPC) and high PC (HPC) after introduction of a new lot of PC antibody.

Drug material, for confirmation (i.e., the drug that is being dosed) is used to confirm positivity of a screening result. Other materials may also be used for confirmation purposes, or for characterization of the immune response (e.g., specificity for multidomain molecules). Changes in confirmation/characterization material lots may therefore affect the confirmatory/characterization reaction when changes in formulation or production have been changed (e.g., host cell protein content). If the drug material is used for labeling and used as coating and detection reagent (i.e., bridging assay formats), changes in material lots may affect labeling efficiency or assay responses. Moreover, even when using the same batch of material, a labeling with comparable efficiency may still result in different assay responses. This underlines the necessity to evaluate the results of the head-to-head comparisons: even if assay responses or ratios are affected, there may be only a negligible effect on the assay.

When new lots of labeled reagents are used, altered assay responses, either increased or decreased, will affect the cut-point that has been used so far. 


\begin{tabular}{|c|c|}
\hline Reagent change & Potential assay impact \\
\hline \multirow[t]{2}{*}{ Matrix } & $\begin{array}{l}\text { May induce drift of negative control responses and impact the assay acceptance criteria and the } \\
\text { cut-point }\end{array}$ \\
\hline & $\begin{array}{l}\text { May induce drift of positive control responses and impact the assay acceptance criteria, the } \\
\text { sensitivity and the titration assay result } \\
\text { May impact selectivity, especially when changing populations }\end{array}$ \\
\hline \multirow[t]{2}{*}{ Positive control antibodies ${ }^{\dagger}$} & $\begin{array}{l}\text { May impact the definition of all assay parameters, especially assay sensitivity, drug tolerance and } \\
\text { specificity }\end{array}$ \\
\hline & May impact the positive control concentration levels \\
\hline \multirow[t]{2}{*}{ Material for confirmatory/characterization assay } & $\begin{array}{l}\text { May impact the confirmatory assay reaction (e.g., by change of formulation, process or host cell } \\
\text { protein content) }\end{array}$ \\
\hline & May impact the functionality in the assay including the cut-point \\
\hline \multirow[t]{3}{*}{ Labeling of coating/detection reagents } & $\begin{array}{l}\text { May impact assay responses in general for example, background noise (which further impacts } \\
\text { cut-point), positive signal level, response ratios, etc }\end{array}$ \\
\hline & May impact assay sensitivity and drug tolerance \\
\hline & May impact labeling efficiency (applicable for bridging assay formats) \\
\hline \multirow[t]{3}{*}{ Coated surfaces } & $\begin{array}{l}\text { May impact assay responses in general for example, background noise (which further impacts } \\
\text { cut-point), positive signal level, response ratios, etc }\end{array}$ \\
\hline & May impact negative control and positive control functionality \\
\hline & May impact homogeneity of coated surfaces \\
\hline Reagents for specific processing steps & May impact the output of the processing step (e.g., acid dissociation, SPEAD, PANDA, etc) \\
\hline
\end{tabular}

Finally, depending on the platform-specific issues that may occur, the introduction of new lots of coated 'plates', or other assay surfaces has the potential to affect assay responses, or the functionality of NC, LPC and HPC. Moreover, the homogeneity of the assay surface may be affected and result in unpredictable variability in assay responses.

\section{Experimental approach to introducing new lots of CR}

Although it is preferable not to introduce new lots of CR during regulated bioanalysis, available storage may be limited to retain indefinite amounts of costly reagents or the reagent availability might be limited. In addition, it is not always possible to estimate the required amounts of materials; the incidence of immunogenicity and the number of assays required in the nonclinical (if required) and clinical studies will be unknown. Sometimes reagents go out of production, or they simply expire, meaning reagent availability can be delayed or retest/expiry dates may be extended. As a result, introduction of new lots of CR is a situation that every bioanalytical scientist will face from time to time.

It is important to point out that ADA assays are not quantitative, since they do not use calibrators. Therefore, simply investigating percentage change with original and new CR lots is not feasible. Therefore, the primary focus should be on the assay functionality and the correct classification (scoring) of positive and negative controls. Additionally, if upper and lower bounds of the controls are used then these should not be negatively impacted. Introduction of a new lot of CR requires verification that the assay is still performing as required and the method has not significantly changed. Obviously, the best way to evaluate this is to compare both the original and new lot head-to-head in the same analytical run(s). This evaluation may be performed in a single run to verify assay functionality, but depending on the CR that is introduced, additional analytical runs may be necessary. In most cases it is adequate to use the standard assay criteria for run acceptance to verify that the assay is performing sufficiently. However, these acceptance criteria are not strictly defined, and assay-specific criteria can be used to justify that the assay is functioning to an acceptable level.

This paper describes the minimal requirements for introduction of new lots of CR in ADA assays. It is to the discretion of the scientist to verify and justify that an ADA assay is performing suitably after introduction of a new lot of CR. Therefore, it may be necessary to perform additional experiments. In agreement with the CR paper for PK assays [1] and with the GBC paper [2], the changes are grouped in minor and major changes. Table 5 shows examples for what could be a minor and major change of CR for an ADA assay. 


\section{Table 5. Examples of minor and major reagent changes.}

\begin{tabular}{|c|c|c|}
\hline Reagent & Examples of minor changes & Examples of major changes \\
\hline Matrix & $\begin{array}{l}\text { Applies to matrix with minimal endogenous } \\
\text { contributions and/or interference factors }\end{array}$ & $\begin{array}{l}\text { Matrix pool with endogenous contribution and/or } \\
\text { interference factors }\end{array}$ \\
\hline Positive control antibodies & $\begin{array}{l}\text { Positive control antibody lot from a new affinity } \\
\text { purification from the same bleed of polyclonal } \\
\text { antibody }\end{array}$ & $\begin{array}{l}\text { Positive control antibody lot from a new affinity } \\
\text { purification from a new bleed from the same animal }\end{array}$ \\
\hline Material for ADA confirmatory/characterization assay & $\begin{array}{l}\text { Drug compound lot production (same formulation) } \\
\text { with the same (or very close) protein concentration }\end{array}$ & $\begin{array}{l}\text { Drug lot with new formulation and/or new protein } \\
\text { concentration }\end{array}$ \\
\hline Labeling of coating/detection reagents & $\begin{array}{l}\text { Labelled reagent with equal or minor difference in } \\
\text { labeling ratio (supported by comparative CR change } \\
\text { data) }\end{array}$ & $\begin{array}{l}\text { Labelled reagent with significant difference in labeling } \\
\text { ratio (supported by noncomparative CR change data) }\end{array}$ \\
\hline Coated surfaces & $\begin{array}{l}\text { Plate lot from a standard plate type where the plate is } \\
\text { not considered a CR }\end{array}$ & $\begin{array}{l}\text { Plate lot from a specialized plate type where the plate is } \\
\text { considered a CR }\end{array}$ \\
\hline Reagents for specific processing steps & Acid buffer lot or preparation change & Bead lot or affinity column change \\
\hline
\end{tabular}

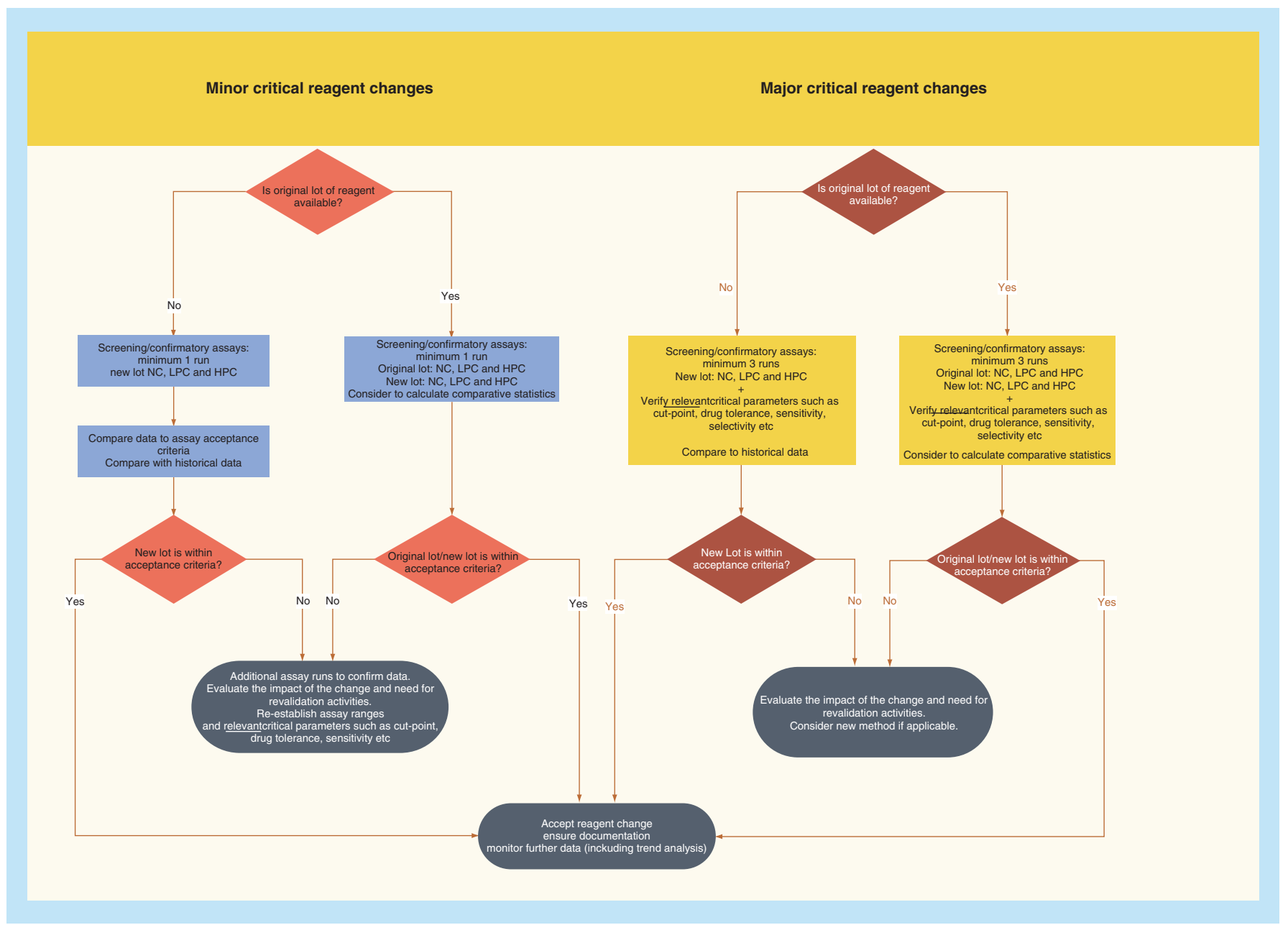

Figure 2. Assay performance tests for minor and major changes of critical reagent in antidrug antibody assay.

EBF recommends the following decision trees (Figure 2) for evaluation of assay performance testing of minor and major changes of CR. It is important to keep in mind that these are the minimum requirements and it may be required to include additional experiments, based on scientific rationale or company policy. 
Once experiments have been performed to evaluate the consequences of introduction of a new CR lot, it is important to document the outcome of these experiments. This documentation should describe the CR that was replaced, the experiments performed, adaptation of the method, the evaluation of results and, most importantly, the justification on these results. Can the method be used unaltered, are minor changes required, what are the consequences for results that were obtained with the method so far?

\section{Introducing new lots of CR: specific approaches}

Depending on the new lot CR that is introduced, different experiments to bridge reagents may need to be performed. The experiments described below summarize the minimum approach that should be taken when introducing new lots of CR.

\section{Blank matrix}

Blank matrix is used for preparation of NC, PC and for dilution of positive samples when performing titration assays. It is advisable to screen individual lots of blank matrix for assay responses in order to prepare a new blank pool that has a comparable assay response to the original lot. It is advisable to verify the original and new lots of NC, LPC and HPC (if available) on the same plate/run, potentially over multiple screening and confirmation runs, if possible. Should the original lot not be available then it is recommended to compare with historical data and assay acceptance criteria. Selectivity and titrations of HPC with both original and new batch of blank pools (if available) should be performed if the $\mathrm{CR}$ change is defined as major.

For comparative assessments, ratios of NC/LPC, NC/HPC, LPC/HPC and/or upper and lower boundaries may be calculated for both original and new blank pool lots and should be comparable. Statistical approaches to evaluate comparability could be considered (e.g., F-test, Bland-Altman). Moreover, when performing titrations of HPC, with original and new blank pool lot, the titer should be within one dilution step or within established intra-assay titration assay precision. Titrations of HPC with original and new blank pool lots will also provide useful information on the sensitivity of the ADA assay, which should be evaluated, if the CR change is defined as major.

It is possible to calculate a new cut-point with the new blank pool lot and to continue analysis with the new cut-point. It is important to verify how big the change in cut-point is with the new lot, as an extensive change in normalisation factor (NF) may introduce a 'break' in the bioanalytical results that were obtained with the previous blank pool lot. Finally, it is possible to accept larger differences at an early phase of drug development, whereas it is desirable to maintain strict acceptance criteria for introducing new lots at a later phase.

\section{$P C \& N C$}

New materials for preparation of LPC, HPC and NC may be necessary at some stage. The PC antibodies are instrumental for the ADA assay, as these antibodies have been used for the assay development and as such have defined the assay attributes. Antibodies that are used for preparation of LPC and HPC are either polyclonal or monoclonal nature. All PC changes should be evaluated in the context of minor or major change. PC lot changes may include several different scenarios, examples are:

- New affinity purification from the same bleed of polyclonal antibody;

- New affinity purification of a new bleed from the same animal;

- Change of production method. As ADA assays are built around PC antibodies, a new production of polyclonal PC antibodies (e.g., new immunization or a new production from a new clone) signifies a new assay and therefore require a full validation.

For PC changes in general, it is recommended that original lots (if available) and new lots of NC, LPC and HPC should be compared head to head in a screening and confirmation assay on the same plate. Should the original lot not be available then it is recommended to compare with historical data and assay acceptance criteria. Assay functionality that should be assessed: are NC, LPC, HPC performing comparable in screening and confirmation. Comparative assessment may include correct classification, ratios between NC/LPC, NC/HPC and LPC/HPC and/or upper and lower boundaries. Should the change be considered a major change, then relevant assay validation parameters, for example sensitivity, selectivity, drug tolerance, cut-point (whatever is applicable) should be assessed. 
Prior to continuation of analyses, it should be verified if the LPC/HPC levels are still correct, or if they require adaptation. In certain cases, behavior of the LPC/HPC is comparable, but a shift in responses may be observed.

\section{Material used for the confirmation/characterization}

The material used will either be the drug compound or other material for characterization.

In the case that drug compound is used in the confirmatory assay and a labeled version is used as a capture and detection reagent in a bridging assay format. Obviously, the drug compound is well characterized, and batch-tobatch differences can be addressed by investigating the certificate(s) of analysis. However, if the concentration or formulation has been significantly changed, further assessment may be required. In the case it is a multiple domain molecule, the required portion to demonstrate specificity may be characterized to the same standard. However, this may not be the case or alternatively you might be sourcing from a commercial vendor. Therefore, additional consideration may be needed.

Drug compound used for labeling: when a new batch of labeled drug is used as capturing and/or detection reagent, it is advised to compare the original (if available) and new batches and to titrate the concentration of the new batches in order to generate comparable assay responses. Assay functionality should be evaluated for both screening and confirmatory reactions. Comparative assessment may include classification, ratios between NC/LPC, NC/HPC, LPC/HPC and/or upper and lower boundaries-these should be comparable. Scientific judgment should be applied with regard to acceptance criteria. Evaluation of the original (or historical data) and new batches in the assay is key, as even batches with comparable labeling efficiencies may result in different assay responses; it may be useful to characterize labeled reagents with regard to labeling efficiency, as provided by commercial sources. For in-house labeling, it is advisable to use the same labeling procedure, and avoid upscaling, as this might impact the labeling efficiency; instead it is recommended to pool several smaller batches, if larger amounts are required.

\section{Coated surfaces}

Depending on the assay format, coated surfaces may be considered to be a CR. It is advised to investigate different lots of coated surfaces during method development to verify if they are considered critical for a particular assay. If this turns out to be the case, it is advised to try to reserve specific lots for this assay. Again, assay functionality in screening and confirmation is key: ratios for NC, LPC and HPC and/or upper and lower boundaries on system suitability controls may be assessed and a plate homogeneity test is advised. Depending on criticality, it may be useful to also verify sensitivity of an ADA assay after introducing a new lot of coated plates. Finally, as a scientific community, it is important to provide feedback to vendors on the consequences of lot-to-lot variations.

\section{Reagents for specific sample processing steps}

Assays may change over time; in early stage of development the assays may not be validated with all parameters whereas for pivotal clinical studies, a fully validated assay is expected by health authorities. Considering this, some specific sample processing steps are used to increase drug tolerance or to select specific ADA entities for example. In this context, when adding an acid dissociation step, using a PandA assay format or applying a pretreatment sample step, additional reagents as PEG, magnetic beads or $\mathrm{pH}$-balanced buffer should be considered as CR. As such, these reagents should be managed like other $\mathrm{CR}$ and their impact on the assay determined.

In certain circumstances, the original lots of critical material may have been depleted and a head-to-head comparison is not possible. Experiments should be performed with the new lot of reagents and the results should be evaluated with historical data. However, if the original material is expired, it is still advisable to test head-to-head with the new reagents and assess alongside previous data.

\section{Method adjustment \& documentation}

Current European Medicines Agency and FDA guidelines do not clearly provide direction on what needs to be documented during an assay life cycle. King $e t$ al. have described best practices for documentation of reagents that are used [2]. However, the Integrated Summary of Immunogenicity (ISI) is a useful place to have change of CR and the impact described $[6,7]$.

As mentioned earlier, introduction of new reagents in an ADA assay may have higher impact, as the consequences are more difficult to assess due to the qualitative nature of the assay. Since current guidelines do not dictate which experiments should be performed to evaluate introduction of new lots of $C R$, it is important to use scientific 
knowledge to verify the potential impact. Moreover, EBF strongly recommends documenting decisions and, most importantly, the justification made regarding assay functionality.

We recommend getting answers to the following questions:

- What changes were implemented to the method?

- What additional assessments were conducted to verify that the new lot is working satisfactorily, or the method has not changed?

- What is the justification to continue with sample analysis after introduction of a new CR lot?

- What consequences were evaluated with regard to previously obtained sample results within a study, that is, is it justifiable to continue with bioanalysis, or has the method been changed to such an extent that (partial) validation is required and sample reanalysis is required?

Just as for CR for PK assays [1], EBF recommends having a formal procedure for reagent handling, qualification and documentation practices to support life cycle management and lot-change decisions. Decisions and justifications should be documented in the appropriate study documentation.

Information on $\mathrm{CR}$ can be documented in a CoA, a technical datasheet, or in other equivalent documentation such as a reagent book. As for the PK assay [1], EBF recommendations for the minimum information on CR is as follows:

- Reagent name;

- Lot number;

- Source (e.g., cell line and method of expression), if applicable;

- Origin source of modified reagents (e.g., labeled reagents);

- Catalog number (commercial reagents, if applicable);

- Concentration (if applicable);

- Retest/expiry date;

- Manufacture date;

- Storage condition recommendation.

\section{Stability}

Reagent stability, characterization and life cycle management is discussed in Rup [10], O'Hara [13] and King [2]. Testing of stability and defining a retest date might be a challenge as many companies use commercial reagents in their assays, which usually come with vendor-specified expiry dates. Stability assessment information is often not available from the vendor and not uncommonly the expiry date is specified as 6-12 months from the delivery date. EBF recommends that stability testing should be based on functional performance in the ADA assay and the use of already existing assay data potentially together with additional stability data and should be the base for the stability evaluation. Re-test dates should be set from experience or procedures and generic stability tables and used for recommendation of suggested re-test periods.

\section{Life-cycle management}

ADA assays may be used in both nonclinical and clinical studies and the recommendations in this paper generally apply to both situations, but the testing strategy may depend on the stage of drug development. However, for ADA assays it should be kept in mind what the results are used for. In the nonclinical studies, antibody results might not even be required, and if required they are used as part of understanding the impact of immunogenicity in correlation with PK and PD data, and the potential impact of the antibodies on PK/TK parameters. For clinical trials, the antibody results are part of the safety assessment. Life-cycle management of CR is therefore of high importance. As later stage clinical trials typically run over a number of years, it might be useful to monitor data over time to provide early detection of potential issues and allow preventative or corrective action. Often assays are transferred to external CROs in later clinical phases, which might also impact the assay and the use of reagents, which might not have originally been considered critical. As mentioned earlier, life-cycle management could be included as part of the ISI. 


\section{Conclusion}

Immunogenicity assays have become an important component in clinical drug development for biotherapeutic products. In order to determine whether a drug is safe, it is imperative to have a reliable and robust immunogenicity assessment.

Just as for LBA PK assays, CR can be identified for immunogenicity assays. In this paper, different CR and the consequences of introducing new lots of CR for immunogenicity assays have been described. The major message from the EBF community is to be aware of the possible impact for introducing new lots of CR in immunogenicity assays. This paper describes the minimum experimental requirements for implementing these new lots and the documentation of changes.

As a minimum requirement, the EBF advises to compare the original and new lots of CR, preferably headto-head for functionality in the actual assay. The major goal of these experiments is to verify if the assay is still performing correctly and has not been altered significantly. In certain circumstances, it may be necessary to perform additional validation experiments to demonstrate appropriate assay functionality without impact on the immunogenicity assessment. However, when these experiments demonstrate that the method underwent major changes, the consequences for already obtained bioanalytical results should be evaluated to decide if it is scientifically justifiable to compare bioanalytical results before and after implementation of the new lot of CR. A final consequence may be that study samples have to be reanalyzed.

Justification and documentation of the reasons for the decisions taken is critical. What are the reasons that justify continuing with the assay or for performing additional (validation) experiments? Finally, what are the consequences for the bioanalytical data that have already been obtained.

While some scientific assessments proposed in this manuscript may be project specific and should not be required for all projects, the EBF recommendations for $\mathrm{CR}$ in $\mathrm{ADA}$ assays are:

- Identify the CR per ADA assay and clearly document in the method documentation (Section 3);

- Ideally, ensure enough material is available to support an entire study and/or drug development program (Section 3);

- Use GBC definitions to evaluate what constitutes a minor or major change (Section 4);

- Where one single lot cannot be sourced for the entire period of use, retain enough material of the original lot for head-to-head comparisons of new lots (Section 4);

- Evaluate lot-to-lot changes of CR using the CoA and test in the ADA assay using a priori criteria (Section 4);

- Method adjustments, change of CR and their impact and justifications could be part of ISI (Section 5);

- Application of re-test dates instead of expiry dates to monitor and evaluate reagent stability (Section 6);

- Assay life cycle management depends of the state of development and the impact of the changes to the assay (Section 7).

Finally, although the EBF recommends performing a functional evaluation of lot-to-lot change in the ADA assay, it also acknowledges that further characterization of the reagents can be implemented to minimize the chance of surprises during testing of new reagent lots. The additional characterization is dependent on the risk that the individual company is willing to take against the additional time and cost of the characterization. Reliable results will be determined independently of the level of characterization applied.

It should also be noted that assay data robustness is independent of the level of reagent characterization applied and a highly characterized assay reagent does not automatically generate more robust assays.

Life-cycle management of CR also allows assay improvement all along the drug development, meaning that $\mathrm{CR}$ management is not only a constraint.

\section{Future perspective}

It is important that the regulatory authorities and the industry agree on the appropriate level of testing for CR. Going forward, the bioanalytical community would welcome open communication with commercial suppliers to ensure more consistency across different reagent lots and potentially longer stability/re-test dates. It would be beneficial for the industry if commercial vendors provide more detailed information regarding reagent characteristics including a fully comprehensive CoA or equivalent documentation. Furthermore, commercial vendors should ensure timely communication to the end users when changes or a cease in production occurs, to allow for timely assessment of the impact in the assay and provide adequate time to take any required mitigation steps. The EBF is also discussing the requirements for $\mathrm{CR}$ for biomarkers and expect to provide recommendations for biomarkers as the last step. 


\section{Acknowledgments}

The authors would like to thank all European Bioanalysis Forum members for very valuable input.

\section{Financial \& competing interests disclosure}

The authors have no relevant affiliations or financial involvement with any organization or entity with a financial interest in or financial conflict with the subject matter or materials discussed in the manuscript. This includes employment, consultancies, honoraria, stock ownership or options, expert testimony, grants or patents received or pending, or royalties.

No writing assistance was utilized in the production of this manuscript.

\section{Disclaimer}

The views and conclusion presented in this paper are those of the European Bioanalysis Forum and do not necessarily reflect the representative affiliation or company's position on the subject.

\section{References}

1. Pihl S, van der Strate BWA, Golob M et al. EBF recommendation on practical management of critical reagents for PK ligand binding assays. Bioanalysis 10(19), 1557-1565 (2018).

2. King LE, Farley $\mathrm{E}$, Imazato $\mathrm{M}$ et al. Ligand binding assay critical reagents and their stability: recommendations and best practices from the global bioanalysis consortium harmonization team. AAPS J. 16(3), E504-E514 (2014).

3. EMA. Immunogenicity assessment of biotechnology-derived therapeutic proteins (2008

- EMEA/CHMP/BMWP/14327/2006). www.ema.europa.eu/en/documents/scientific-guideline/guideline-immunogenicity-assessme nt-biotechnology-derived-therapeutic-proteins-first-version_en.pdf

4. EMA. Immunogenicity assessment of monoclonal antibodies intended for in vivo clinical use (2012 -

EMA/CHMP/BMWP/86289/2010). www.ema.europa.eu/en/documents/scientific-guideline/guideline-immunogenicity-assessment -monoclonal-antibodies-intended-vivo-clinical-use_en.pdf

5. EMA. Guideline on similar biological medicinal products (2015 - CHMP/437/04 Rev

1). www.ema.europa.eu/en/documents/scientific-guideline/guideline-similar-biological-medicinal-products-rev1_en.pdf

6. EMA. Guideline on Immunogenicity assessment of therapeutic proteins (2017 - EMEA/CHMP/BMWP/14327/2006 Rev 1). www. ema.europa.eu/en/documents/scientific-guideline/guideline-immunogenicity-assessment-therapeutic-proteins-revision-1_en.pdf

7. FDA. Immunogenicity testing of therapeutic protein products - developing and validating assays for anti-drug antibody detection (2019). www.fda.gov/media/119788/download

8. USP. Immunogenicity assays - design and validation of immunoassays to detect anti-drug antibodies. UPS 41(1106), 7264-7279 (2018).

9. Mire-Sluis AR, Barret YC, Koren E et al. Recommendations for the design and optimization of immunoassays used in the detection of host antibodies against biotechnology products. J. Immunol. Methods 289, 1-16 (2004).

10. Rup B, O’Hara D. Critical ligand binding reagent preparation/selection: when specificity depends on reagents. AAPS J. 9(2), E148-E155 (2007).

11. Shankar G, Devanarayan V, Amaravadi L et al. Recommendations for the validation of immunoassays used for detection of host antibodies against biotechnology products. J. Pharm. Biomed. Anal. 48(5), 1267-1281 (2008).

12. Staack R, Stracke JO, Stubenrauch K, Vogel R, Scheypen J, Papadimitriou A. Quality requirements for critical assay reagents used in bioanalysis of therapeutic proteins: what bioanalysts should know about their reagents. Bioanalysis 3(5), 523-534 (2011).

13. O'Hara D, Theobald V, Egan AC et al. Ligand binding assays in the $21^{\text {st }}$ century laboratory: recommendations for characterization and supply of critical reagents. AAPS J. 14(2), 316-328 (2012).

14. Geist BJ, Egan AC, Yang TY et al. Characterization of critical reagents in ligand-binding assays: enabling robust bioanalytical methods and lifecycle management. Bioanalysis 5(2), 227-244 (2013).

15. O'Hara DM, Theobald V. Life cycle management of critical ligand-binding reagents. 5(21), 2679-2696 (2013).

16. Xu ASL, Weant J. Chapter 8, critical reagent stability for immunogenicity assays. Future Science 93-106 (2013).

17. King L, Farley E, Imazato $\mathrm{M}$ et al. Ligand binding assay critical reagents and their stability: recommendations and best practices from the Global Bioanalysis Consortium Harmonization Team. AAPS J. 16(3), 504-515 (2014).

18. Lefor Bradford J. Sponsor relationships, analyte stability in ligand-binding assays and critical reagent management: a bioanalytical CRO perspective. Bioanalysis 7(11), 1337-1346 (2015).

19. Ishii-Watabe A, Shibata H, Nishimura K et al. Immunogenicity of therapeutic protein products: current considerations foranti-drug antibody assay in Japan. Bioanalysis 10(2), 95-105 (2018). 